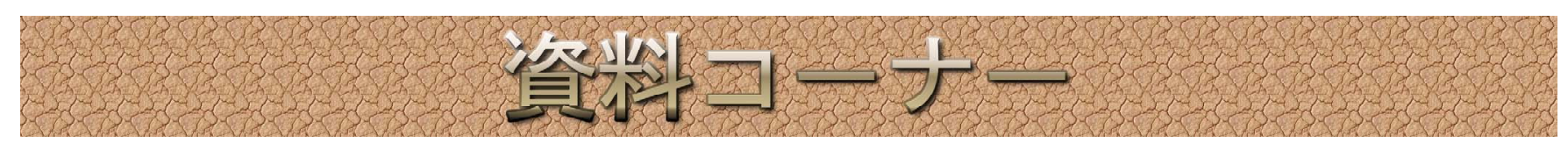

\title{
スマートグリッド共同実証研究
}

出典 : 新エネルギー・産業技術総合開発機構（NEDO）海外レポートNo1054 (2009.11.4)

(http://www.nedo.go.jp/kankobutsu/report/1054/1054-01.pdf ) より抜粋

近年、世界的にスマートグリッドの話題が盛り上がって おり、欧州、特に米国では、研究機関等による実証計画が 進んでいます。新エネルギー・産業技術総合開発機構 (NEDO) も、日本の系統連係技術の世界的展開を睨み、米国ニュー メキシコ州と共同実証研究を始めました。本資料は、この スマートグリッドのコンセプトについて、NED0の共同実証 レポートから抜粋したものです。（以下引用）

\section{1. スマートグリッドとは}

スマートグリッド (smart grid) という言葉は、その同義 語であるインテリグリッド(intelligent grid)という言葉 などとともに、4〜 5 年前から欧米で使われていた。スマー トグリッドの意味は分かりにくいとよく言われるが、この 言葉は具体的な技術を指すのではなく、「電力システムの イノベーションの方向性を示した政策用語」と理解すると わかりやすい。

欧州では、スマートグリッドの名前の下で、都市エリア のエネルギー需給システムの最適化を目指して、新エネル ギーのみでなくコージェネレーションなどの熱利用も含め て展開してきた。米国では、電力市場の安定化を目指して スマートメーターの利用を奨励する形で進行してきた。日 本では、技術者を中心に配電自動化を中心とする電力シス テムのイノベーションが中心と捉えられる傾向が強い。す なわち、欧州では社会科学者の理想を追うものとして、米 国では経済学者の理想を追うものとして、日本ではエンジ ニアの理想を追うものとして表現されてきた。そのため、 日米欧でスマートグリッドは異なるものと理解されがちで あるが、「送電、配電、需要家、と階層化された電力シス テムにおける情報化投資を進めるもの」と捉えると世界的 に共通点があり、例えれば富士山にどこから登っても頂上 に達するように、最後は似たものに収束すると予想されて いる。

特に今後、太陽光やコージェネなどの分散電源を需要家 が持つことにより、電力会社側と分散電源を持つ需要家側 が、何らかの情報交換を進める必要が出てきたことが重要 な変化である。

\section{2. ロスアラモス郡での実証ハウス}

NEDO 実証八ウスでは、系統側からの料金信号及び気象情 報を取り込んで、新エネルギーの余唾発電電力を最大限吸 収できるデマンドレスポンスを実証する事が目的である。 実証ハウスでは、数 $\mathrm{kW}$ の住宅用太陽光発電設備を設置し、 その最適利用を検討するため、住宅用の太陽光発電での余 剰吸収に十分な $20 \mathrm{kWh}$ クラスの蓄電池（日本ではこのよう
な大容量のものは、法律の定めにより設置できない）、あ るいはヒートポンプ温水蓄熱装置、電気自動車などを導入 する。これらを管理するインテリジェントサーバーを導入 し、配電系統側信号や気象情報を取り込み、蓄エネルギー を最適運転するシステムを構築する。

なお、原則的に、模擬負荷パターンを設定して、日米の 住宅エネルギーの異なる需要パターンを再現するものとし 宅内情報ネットを使い、そのほかにも料金信号により制御 可能な需要についてもデマンドサイド（需要家側）マネー ジメントの可能性を検討する予定である。宅内ネットワー クおよび住宅までのアクセスネットワークについては、さ まざまな方法を検証したいと考えている。合わせて総括研 究側と協調し、サイバーセキュリティの日米での共同評価 の際には、検証した様々な方法を沮上に載せる事を想定し ている。

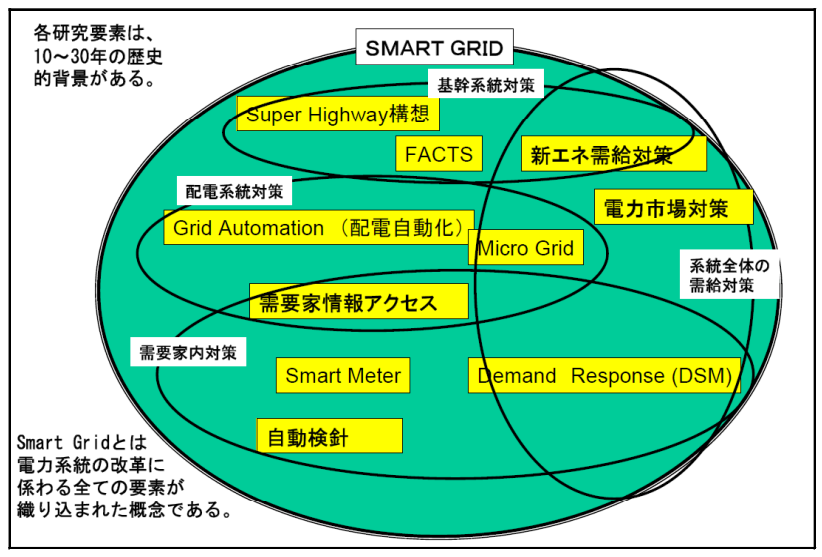

図 1 : 米国におけるスマートグリッドが包含する技術コンセプト

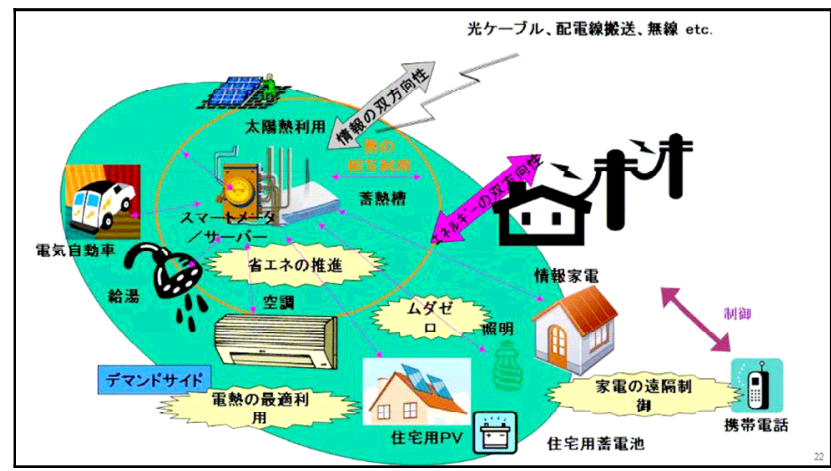

図 2 : 宅内エネルギー管理の概念

ルベン・インスンサ（東芝三菱電機産業システム)

(平成 22 年 1 月 8 日受付) 